\title{
ANALISIS NATIVE ADVERTISING SEBAGAI KONTEN MEDIA ONLINE DREAMERS.ID
}

\author{
Cemara Drearsita Dinanti ${ }^{1}$, A. Sigit Pramono Hadi ${ }^{2}$ \\ 1,2Broadcasting, Ilmu Komunikasi, Sekolah Tinggi Ilmu Komunikasi InterStudi \\ Jl. Wijaya II No. 62, Jakarta 12160 \\ ${ }^{1}$ cemaradrearsita@gmail.com ${ }_{2}{ }^{2}$ sigitvt35@gmail.com
}

\begin{abstract}
Abstrak: Native advertising secara halus menyesuaikan bentuk kontennya dengan media yang menerbitkannya. dreamers.id sebagai media online yang secara masif menyebarkan konten native advertising namun memiliki bounce rate rendah dibanding kompetitor lain. Penelitian ini bertujuan untuk mengeksplorasi bagaimana native advertising sebagai konten media online dalam dreamers.id. Pendekatan penelitian mengunakan metode kualitatif dan bersifat deskriptif. Penelitian dilakukan dengan mewawancarai empat informan yang terdiri dari Kepala Redaksi dreamers.id, Account Executive dreamers.id, Marketing Executive CIMB Niaga, dan audiens. Dari hasil penelitian diperoleh bahwa konten native advertising yang dihasilkan oleh dreamers.id memuat pesan informasi dan merek. Penyebaran konten native advertising dilakukan melalui semua platform yang dimiliki dreamers.id seperti website, radio online, dan media sosial. Selain itu, keterlibatan komunitas, akun sosial media berbayar, serta kerjasama dengan influencer dan kanal berita lain juga dilakukan untuk memperluas penyebaran konten native advertising. Hal ini agar mencapai objektif yang telah ditentukan sehingga dapat berdampak bagi dreamers.id, pengiklan, maupun audiens. Konten native advertising mampu membentuk awareness dari audiens, namun belum dapat mencapai tujuan lain dalam beriklan. Hasil dari penelitian ini diharapkan menjadi kajian dan acuan dalam membentuk konten native advertising secara efektif.
\end{abstract}

Kata Kunci: Native advertising, Media Online, Online Advertising

Abstract: Native advertising subtly adapts the form of its content to the publisher. dreamers.id as an online media massively spreads native advertising content but has a low bounce rate compared to other competitors. This study aims to explore how native advertising as online media content in dreamers.id. The research uses qualitative approach and descriptive methods. The research was conducted by interviewing four informants consisting of the Chief Editor of dreamers.id, the Account Executive of dreamers.id, the Marketing Executive of CIMB Niaga, and the audience. This research found that the native advertising content produced by dreamers.id contains information and brand messages. dreamers.id spread native advertising content through all theirs platforms, such as website, online radio, and social media. In addition, community involvement, paid social media accounts, collaboration with influencers and other news channels are also carried out to expand the spreadability of native advertising content. This way can achieve predetermined objectives so it can impact dreamers.id, advertisers, and the audience. Native advertising content able to build awareness from the audience, but it has not been able yet to achieve another goals in advertising. The results are expected to be a study and reference in creating native advertising content effectively.

Keywords: Native advertising, Online Media, Online Advertising 


\section{PENDAHULUAN}

Native advertising telah menjadi cara baru dalam beriklan (Del Rey, 2013) yang dibuat agar para audiens merasa nyaman dalam mengonsumsi sebuah konten yang berisi iklan (Schauster, Ferrucci dan Neill, 2016). Iklan ini menyesuaikan bentuk dan format sesuai dengan editorial media yang mempublikasikannya sehingga sekilas tak tampak seperti iklan (Aribarg dan Schwartz, 2020). Tidak hanya meniru konten berita dalam tampilan, gaya penulisan dan visual native advertising juga dibuat mirip dengan format jurnalistik yang biasa dipakai oleh media yang memublikasikannya. Misalnya, dapat menggunakan font yang sama; URL yang sama; dan membagikan gambar yang bersumber dari ruang berita media tersebut (Sirrah, 2019).

Setiap media memiliki gaya penulisannya masing-masing. Jika membicarakan mengenai gaya bahasa iklan, maka tidak luput dari copywriting. Copywriting merupakan seni penulisan yang mengandung pesan penjualan secara persuasif yang kuat. Menurut Frank Jefkins, tulisan yang dimuat dalam copywriting harus dikemas dengan gaya bahasa yang menarik dan kreatif. Copywriting dapat dihasilkan dengan perencanaan dan kerjasama dengan klien, staf legal, account executive, peneliti, dan juga direktur seni. Pelaku yang membuat copywriting disebut copywriter. Copywriter ini harus dapat menuangkan kreativitasnya dalam bentuk tulisan yang menarik, impresi, mudah dimengerti dan persuasif (Agustrijanto, 2006).

Menurut Frank Jefkins dalam Harina (2019) copywriting tersusun dari berbagai unsur seperti tipografi, headline, subheadline, bodycopy dan closing word. Tipografi adalah seni memilih jenis, desain, ketebalan, dan ukuran huruf yang kemudian digabungkan menjadi sejumlah kata ke dalam keadaan ruang yang tersedia. Headline memuat judul iklan yang terletak paling atas di awal tulisan dengan ukuran huruf yang besar. Headline dapat dikatakan menarik apabila audiens memutuskan untuk membaca isi selanjutnya serta memberikan rasa ingin tahu tentang iklan yang disampaikan. Subheadline atau kalimat peralihan yang menjelaskan makna headline. Kalimat ini terletak di antara headline dan bodycopy (kalimat pembuka naskah). Bodycopy memberikan bagian isi tulisan yang ingin 
disampaikan secara jelas dan detail. Isi teks dikemas secara kreatif dan menarik sehingga para audiens penasaran dan membuat mereka membaca secara keseluruhan. Closing word berisikan kalimat singkat yang jelas berupa info penjualan atau info produk yang bertujuan untuk mengarahkan para audiens dalam membuat keputusan (Pujiriyanto, 2005).

Native advertising mengandung dua komponen yaitu konten informasi/editorial content dan informasi tentang pengiklan/ sponsorship (The Interactive Advertising Bureau (IAB), 2019). Komponen informasi dikemas dalam sebuah artikel berita. Konten ini memberikan informasi dan pengetahuan bagi para audiens (Tarigan, 2015). Komponen informasi seputar pengiklan memberikan pesan komersial sebuah produk secara halus (Apostol, 2020).

Meskipun terdapat kemiripan, native advertising harus mencantumkan siapa yang mensponsori konten tersebut (Federal Trade Commission, 2015). Media yang memiliki native advertising biasanya memberi label khusus dengan istilahnya masingmasing seperti Sponsored Content, Paid Post, Branded Content, Partner Content dan lain-lain (Tarigan, 2015). Hal ini bertujuan agar audiens dapat membedakan artikel editorial dari redaksi dan native advertising. Selain itu juga dapat mempertegas mana yang berisi konten editorial maupun konten native advertising (Schauster, Ferrucci dan Neill, 2016). Hal ini juga diatur dalam Peraturan Dewan Pers Nomor 1/PeraturanDP/III/2012 tentang Pedoman Pemberitaan Media Siber yang mengatakan media online harus membedakan secara tegas antara produk berita dan iklan dengan mencantumkan label "advertorial”, "iklan", "ads", "sponsored", atau kata lain yang menjelaskan bahwa berita/artikel/isi tersebut adalah iklan (Dewan Pers, 2017).

Native advertising terbagi menjadi tiga kategori; Sponsored Content, Sponsored Hyperlink Listings, dan Sponsored Social Media Posts (Wojdynski, 2016a). Sponsored content merujuk kepada bentuk iklan yang serupa dengan konten asli media yang mempublikasikannya (Wojdynski, 2016a). Sponsored Hyperlink Listings menyajikan tautan di luar situs penerbit pada sebuah situs yang berfungsi untuk mengarahkan audiens ke konten dalam situs lain. Situs penerbit befungsi sebagai pihak yang merujuk yang ditandai dengan label "rekomendasi konten" atau 
"penemuan konten". Secara fungsional, sponsored hyperlink listings berbeda dengan sponsored content. Sponsored content memiliki konten asli yang dibuat untuk iklan, sedangkan sponsored hyperlink listings hanya meneruskan atau merujuk audiens ke konten lain dengan biaya tertentu. Kategori ini dianggap sebagai native advertising karena hyperlink tampak mirip sebagai sebuah kesatuan dalam sebuah situs, padahal tidak demikian (Wojdynski, 2016a). Sponsored Social Media Posts menampilkan teks dan gambar yang terbatas tentang produk tertentu pada media sosial. Pada kategori ini, format iklan didasarkan pada media sosial itu sendiri. Misalnya sponsored social media posts di Twitter berlabel "promoted", Facebook dengan "sponsored posts" dan pada Linkedln dengan "sponsored updates"(Wojdynski, 2016a).

Native advertising lebih efektif (Vranica, 2016) dan menarik untuk digunakan daripada jenis iklan digital lainnya (Wang dan Huang, 2017) serta melibatkan beberapa pihak seperti pengiklan, penerbit, dan audiens (Tutaj dan van Reijmersdal, 2012; Probst, Grosswiele dan Pfleger, 2013; Harms, Bijmolt dan Hoekstra, 2017) yang bertujuan untuk; para pengiklan agar mencapai tujuan komunikasi pemasaran (Harms, Bijmolt dan Hoekstra, 2017); penerbit menghasilkan pendapatan alternatif (Probst, Grosswiele dan Pfleger, 2013); serta audiens mendapatkan nilai lebih dari sekedar iklan biasa (Tutaj dan van Reijmersdal, 2012).

Dengan memasukkan secara halus unsur iklan pada konten editorial, native advertising semakin digemari oleh para pengiklan karena membuat audiens lebih terkesan dibanding iklan digital lainnya (Kim, Pasadeos dan Barban, 2001; Tutaj dan van Reijmersdal, 2012). Konten native advertising terasa lebih informatif, lebih menarik, dan tidak terlalu mengganggu (Tutaj dan van Reijmersdal, 2012). Daya tarik pesan dan keunggulan sebuah merek menjadi penting dalam efektivitas konten native (Harms, Bijmolt dan Hoekstra, 2017).

Menurut Holbrook dan Batra dalam Harms, Bijmolt dan Hoekstra (2017) ada dua tipe pesan dalam konten iklan; konten iklan yang bersifat informasional memuat fakta seputar produk; konten iklan yang bersifat emosional mengandung informasi berdasarkan karakteristik psikologis yang berkaitan dengan pengalaman audiens (Harms, Bijmolt dan Hoekstra, 2017). Konten yang berkaitan dengan emosional dapat 
membuat keterikatan audiens lebih besar (Berger dan Milkman, 2012). Namun, penelitian terdahulu mengatakan sebagian besar pengiklan menggunakan konten informasional agar tetap terjalin ikatan antara merek dan audiens (Ashley dan Tuten, 2015).

Native advertising menggunakan pendekatan yang halus sehingga membuat visibilitas sebuah merek menjadi rendah karena letaknya yang tidak terlalu terlihat mulai dari nama, logo, maupun URL sebuah merek (Wojdynski, 2016a, 2016b). Apabila sebuah merek tidak terlalu mencolok atau unggul, maka sebuah konten tidak dapat membuat audiens terhubung dengan suatu merek (Van Reijmersdal, 2009). Meskipun merek tidak terlalu menonjol pada konten native, audiens tetap dapat memperoleh pengetahuan tentang bagaimana, mengapa, dan kapan yang tujuannya untuk mempersuasi (Boerman et al., 2014). Sebaliknya, apabila keunggulan merek terlalu menonjol, maka dapat mengarahkan kepada evaluasi audiens yang negatif dan menurunkan tingkat engagement pada konten tersebut (Harms et al., 2017; Van Reijmersdal, 2009; Wojdynski dan Evans, 2016).

Native advertising lebih dulu populer pada media online (Whittle dan Xue, 2018) karena memiliki jangkauan luas dan penyebaran yang cepat (Bakshi, 2015). Media online merupakan media berbasis internet yang dapat menghubungkan media dengan orang lain (Dewan Pers, 2012; Romli, 2014; Siapera, 2017). Media online dapat menyatukan berbagai konten yang sebelumnya berdiri sendiri seperti konten dalam media cetak, radio maupun televisi (Ashari, 2019). dreamers.id sendiri memiliki beragam media online seperti website, radio online, dan media sosial (dreamers.id, 2020) untuk menyebarkan beragam konten.

Seiring dengan berpindahnya jurnalisme konvensional ke digital (Carlson, 2014) membuat portal berita online terpercaya seperti The New York Times, The Atlantic, dan The Washington Post menerapkan penggunaan native advertising kedalam konten mereka. The New York Times mempublikasikan sebuah artikel berjudul "Women Inmates: Why the Male Model Doesn't Work" pada 2014 (T Brand Studios, 2014). Konten native advertising ini bekerjasama dengan Netflix untuk memperkenalkan series berjudul Orange Is The New Black. Artikel ini memuat fakta 
dan data seputar narapidana wanita sehingga serupa dengan konten jurnalistik (Lazauskas, 2014).

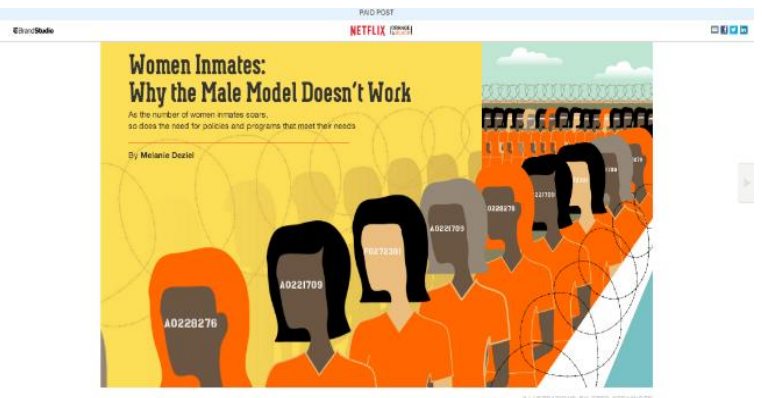

Gambar 1 Konten Native advertising The New York Times Sumber : www.nytimes.com

The Atlantic pernah bekerjasama dengan perusahaan teknologi dan informasi bernama IBM dalam pembuatan artikel native advertising (Morey, 2019). Artikel berjudul "Blood, Sweet, and Data" ini memuat informasi tentang kekuatan data dalam olahraga (The Atlantic, 2019). Konten ini sekaligus memperkenalkan teknologi terbaru dalam olahraga. Banyak data visual yang diselipkan seperti statistik dalam bentuk infografis, galeri foto, dan wawancara. Visual ini membantu memperkuat narasi di dalamnya.

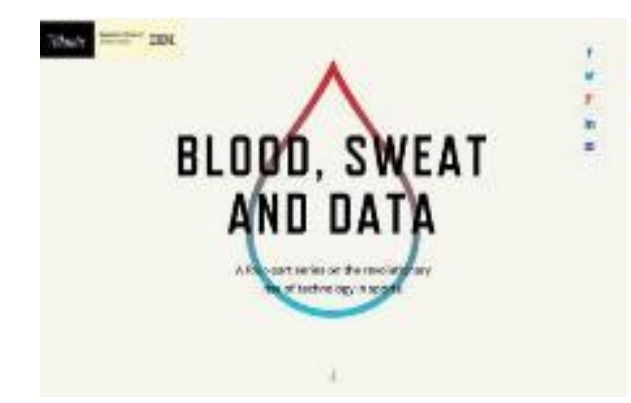

Gambar 2 Konten Native advertising The Atlantic Sumber : www.theatlantic.com

Tim Brand Studio dalam The Washington Post pernah membuat sebuah artikel yang berjudul "The Rise of The Superhuman" (Brand Studio, 2019). Konten native advertising ini bekerja sama dengan brand mobil Mercedes-Benz yang memuat tentang teknologi seperti virtual reality dan pakaian robot (Kloot, 2019). Sebenarnya, artikel ini bertujuan untuk memperkenalkan fitur baru kendaraan kelas E-Mercedes. 


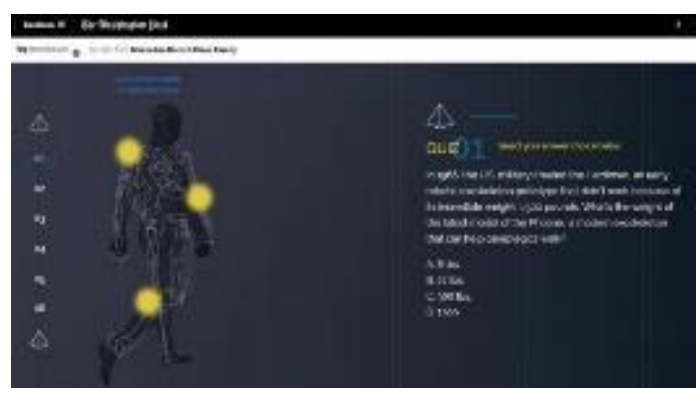

Gambar 3 Konten Native advertising The Washington Post Sumber : www.washingtonpost.com

Media berita online dreamers.id menjadi objek pada penelitian ini. dreamers.id mengintegrasikan antara streaming radio, youth web portal, event, sosial media, serta komunitas (dreamers.id, 2020). Data analisis website dreamers.id menunjukkan bahwa bounce rate berada pada angka 45,8 \%, sedangkan rata-rata bounce rate website kompetitor memiliki angka 72,1\% (Alexa, 2020). Bounce rate merupakan persentase visitor yang berkunjung lalu meninggalkan web setelah membuka halaman pertama, semakin kecil angka bounce rate maka akan semakin optimal sebuah web (Syahrial, Munadi dan Mardatillah, 2010). Selain itu, rata-rata audiens menghabiskan waktu berkunjung ke website sebanyak 7 menit 38 detik per hari nya (Alexa, 2020). dreamers.id juga memiliki beragam media sosial serta menaungi 671 fanbase dan komunitas kpop maupun nonkpop yang tergabung di dalamnya (dreamers.id, 2020). Semua platform tersebut juga digunakan untuk menyebarkan konten native advertising. Fenomena dreamers.id yang menyebarkan konten native advertising secara masif namun memiliki bounce rate yang rendah ini menjadikan penelitian ini menarik dan penting untuk diteliti lebih lanjut. Penelitian ini ingin mengeksplorasi bagaimana native advertising sebagai konten media online dalam dreamers.id. Selain itu, penelitian ini diharapkan dapat menjadi referensi dalam menciptakan konten native advertising dalam sebuah media online.

Beberapa penelitian sebelumnya lebih mengkaji bagaimana konten native advertising berdampak pada kredibilitas media yang mempublikasikan konten tersebut (Carlson, 2014; Schauster, Ferrucci dan Neill, 2016; Wu et al., 2016). Namun, penelitian tersebut belum terlalu mengulas tentang bagaimana sebuah media mengelola konten native advertising sebagai salah satu konten dari media tersebut. 
Penelitian ini memberikan kebaruan tentang pemahaman bagaimana media online (dreamers.id) mengelola konten native advertising sehingga dapat meningkatkan engagement dan awareness audiens.

Penelitian terdahulu mengungkapkan bahwa kurang dari 8\% audiens menyadari konten native adalah sebuah iklan (Wojdynski dan Evans, 2016). Konten native advertising dikemas secara kreatif dan menghibur (Whittle dan Xue, 2018). Namun, tidak dipungkiri beberapa audiens ada yang merasa tertipu akan keutuhan informasi sebuah konten sehingga mengabaikan merek yang tersemat di dalamnya (Whittle dan Xue, 2018).

Native advertising berupaya menciptakan awareness (kesadaran), interest (ketertarikan), dan attitude change (perubahan sikap) audiens. Meskipun belum dapat berdampak sampai kedalam membuat keputusan pembelian, native advertising efektif untuk menciptakan promosi dari mulut ke mulut (Harms, Bijmolt dan Hoekstra, 2017). Publisher juga mendapatkan penghasilan alternatif (Probst, Grosswiele dan Pfleger, 2013) dalam menghasilkan konten native advertising.

\section{METODE PENELITIAN}

Penelitian ini menggunakan metode penelitian kualitatif. Penelitian kualitatif memandang objek sebagai sesuatu yang dinamis, hasil konstruksi pemikiran, dan holistik karena setiap aspek memiliki kesatuan yang tidak dapat dipisahkan serta dapat mempelajari secara mendalam mengenai isu atau kejadian yang terpilih (Sugiyono, 2008). Metode ini digunakan untuk memperoleh gambaran utuh bagaimana native advertising sebagai konten media online dalam dreamers.id.

Penelitian ini bersifat deskriptif dengan cara mengumpulkan data-data dalam bentuk kata-kata atau gambar, bukan pada angka (Sugiyono, 2008). Metode wawancara mendalam dipilih untuk mendapatkan informasi pada tingkat detail yang lebih dalam (Hatzios dan Lariscy, 2008). Teknik triangulasi dipilih sebagai cara dalam mengumpulkan data (Sugiyono, 2008). Triangulasi menggabungkan observasi, wawancara mendalam, dan dokumentasi agar dapat meningkatkan kekuatan data. Peneliti memilih informan berdasarkan kriteria purposif, di mana memilih sumber 
data berdasarkan sumber yang dianggap paling mengetahui atau menguasai suatu masalah yang diangkat oleh peneliti (Sugiyono, 2008).

Tabel 1 Data Informan Penelitian

\begin{tabular}{|c|c|c|c|c|}
\hline $\begin{array}{l}\text { Karakteristik } \\
\text { informan }\end{array}$ & Informan 1 & Informan 2 & Informan 3 & Informan 4 \\
\hline Nama & Reinata Meissa & $\begin{array}{l}\text { Yuyun } \\
\text { Wahyuningsih }\end{array}$ & $\begin{array}{l}\text { Muhammad } \\
\text { Adli }\end{array}$ & Angan Kinanti \\
\hline Pekerjaan & $\begin{array}{l}\text { Kepala Redaksi \& } \\
\text { Sosial Media } \\
\text { Dreamers.id }\end{array}$ & $\begin{array}{l}\text { Account } \\
\text { Executive } \\
\text { Dreamers.id }\end{array}$ & $\begin{array}{l}\text { Brand Strategy - } \\
\text { Marketing Executive } \\
\text { CIMB Niaga }\end{array}$ & Mahasiswi \\
\hline
\end{tabular}

Sumber : Dinanti, 2020

Peneliti memilih Kepala Redaksi \& Sosial Media dreamers.id, Account Executive dreamers.id, Brand Strategy - Marketing Executive CIMB Niaga, dan mahasiswi yang sering membaca berita melalui media online sebagai informan. Peneliti memilih sumber-sumber tersebut didasarkan pada kemampuan dan penguasaan terhadap ruang lingkup tema penelitian sebagai upaya untuk menangkap variasi-variasi besar dari responden (Poerwandari, 2007).

Hasil wawancara dituangkan dalam bentuk transkrip lalu diolah dengan proses koding. Pada tahap transkripsi, data hasil wawancara berupa rekaman diproses menjadi bentuk tertulis/teks tanpa mengubah, menyesuaikan, ataupun menyimpulkan hasil rekaman yang menggambarkan secara apa adanya sehingga peneliti tidak melakukan penyesuaian apapun. Selanjutnya, proses koding dilakukan dengan mengolah data dengan menggunakan bagian dari kata-kata pada transkrip agar dapat melakukan analisis data secara mudah dan akurat (Manzilati, 2017).

Setelah membaca seksama dan mengenali isi dari teks, maka tahapan selanjutnya adalah pengkodean (coding). Pengkodean merupakan proses mengolah data dengan menggunakan bagian dari kata-kata pada transkrip agar dapat melakukan analisis data secara mudah dan akurat. Tahap pertama dalam pengkodean adalah open coding. Open coding dilakukan dengan proses mempelajari data dan memberikan kode pada data tersebut. Tahapan selanjutnya adalah axial coding. Pada tahap ini peneliti mengidentifikasi axis dari konsep utama dengan melakukan pencarian sebab akibat, pola interaksi, kategori, dan kelompok konsep 
yang kemudian dapat membentuk kategori atau dimensi baru atas pemahaman. Selective coding merupakan tahap akhir di mana proses mencari fakta atau bukti yang dapat mengilustrasikan tema tertentu agar mendapat pemahaman tema tersebut secara kontekstual (Manzilati, 2017). Setelah melalui berbagai tahapan, didapat beberapa temuan yang menjelaskan bagaimana native advertising sebagai konten dalam dreamers.id baik dalam kategori, ciri, tujuan, proses, penggunaan, dampak, serta peran media online.

Penelitian ini menggunakan analisis tematik sebagai teknik dalam menganalis data yang telah diolah. Analisis tematik merupakan sebuah proses pengkodean informasi sehingga menghasilkan daftar tema, indikator yang kompleks, kualifikasi tema, atau gabungan (Poerwandari, 2007). Peneliti menggunakan analisis tematik dengan alasan dapat membangun subtema berupa konten, penyebaran dan dampak dari native advertising .

Dalam menguji keabsahan data, penelitian ini menggunakan triangulasi dalam pengujian kredibilitas yang berarti pengecekan data dari berbagai sumber, teknik pengumpulan data, dan waktu. Teknik triangulasi sumber merupakan teknik untuk menguji kredibilitas data dengan cara mengecek data yang telah diperoleh melalui beberapa sumber. Lalu, teknik triangulasi pengumpulan data dilakukan dalam bentuk pengecekan data dengan sumber yang sama namun menggunakan teknik berbeda seperti wawacara, observasi, dan dokumentasi. Setelah itu, teknik triangulasi waktu juga dilakukan dengan pengecekan data berulang kali dalam waktu dan situasi yang berbeda (Sugiyono, 2008).

\section{HASIL DAN DISKUSI}

Berdasarkan penelitian yang telah dilakukan dengan meninjau hasil wawancara dari sudut pandang empat orang informan yang diteliti, maka didapatkan temuan yang menggambarkan keseluruhan konten native advertising yang dihasilkan dreamers.id, lalu cara menyebarluaskan konten tersebut dengan menggunakan berbagai macam media yang dimiliki dreamers.id hingga dampak yang diperoleh melalui konten native advertising. 


\section{Tabel 2 Ringkasan Hasil Analisis}

\begin{tabular}{|c|c|c|c|c|c|}
\hline & & Informan 1 (RM) & Informan 2 (YW) & Informan 3 (MN) & Informan 4 (AK) \\
\hline \multirow{5}{*}{$\begin{array}{l}\text { Konten } \\
\text { Digital Native } \\
\text { advertising }\end{array}$} & $\begin{array}{l}\text { Jenis Native } \\
\text { advertising yang } \\
\text { Dihasilkan }\end{array}$ & $\begin{array}{l}\text { sponsored content, sponsored } \\
\text { hyperlink listings, serta } \\
\text { sponsored social media posts }\end{array}$ & $\begin{array}{l}\text { sponsored content, sponsored hyperlink } \\
\text { listings, sponsored social media posts, } \\
\text { kadang diolah dalam bentuk event dan } \\
\text { program radio }\end{array}$ & - & - \\
\hline & $\begin{array}{l}\text { Pedoman } \\
\text { Pembuatan } \\
\text { Konten Native } \\
\text { advertising }\end{array}$ & $\begin{array}{l}\text { tetap menjunjung tinggi } \\
\text { pedoman jurnalistik, } \\
\text { menyesuaikan dengan standar } \\
\text { kualitas dan identitas dreamers } \\
\text { serta menyesuaikan dengan } \\
\text { objektifitas klien }\end{array}$ & $\begin{array}{l}\text { Pedomannya pada brief, target, dan KPI (Key } \\
\text { Performance Indicator) dari klien }\end{array}$ & - & - \\
\hline & $\begin{array}{l}\text { Ciri-Ciri Konten } \\
\text { Native } \\
\text { advertising }\end{array}$ & $\begin{array}{l}\text { menyematkan label } \\
\text { "advertorial", terdapat } \\
\text { informasi editorial dan } \\
\text { informasi mengenai merek/ } \\
\text { product knowledge, penulisan } \\
\text { bersifat persuasif, pada judul } \\
\text { dan thumbnail tidak terdapat } \\
\text { informasi seputar merek, serta } \\
\text { informasi merek dibuat sangat } \\
\text { halus }\end{array}$ & $\begin{array}{l}\text { Tema yang diangkat biasanya ringan dan } \\
\text { tren yang disesuaikan dengan segmentasi } \\
\text { dan informasi produk serta kontennya } \\
\text { bersifat soft-selling }\end{array}$ & - & - \\
\hline & $\begin{array}{l}\text { Tujuan } \\
\text { Menggunakan } \\
\text { Konten Native } \\
\text { advertising }\end{array}$ & $\begin{array}{l}\text { jumlah visitor maupun klik ke } \\
\text { website klien, mencapai } \mathrm{KPI} \\
\text { (key performance indicator), } \\
\text { dan memperkaya varian artikel } \\
\text { yang dihasilkan }\end{array}$ & $\begin{array}{l}\text { Mendapatkan revenue dari iklan, } \\
\text { tercapainya KPI, dan meningkatkan } \\
\text { engagement }\end{array}$ & $\begin{array}{lr}\text { mendapatkan } & \text { reach, } \\
\text { downloader, } & \text { dan } \\
\text { awareness } & \text { dari } \\
\text { audiens } & \end{array}$ & - \\
\hline & $\begin{array}{l}\text { Tahapan } \\
\text { Pembuatan } \\
\text { Konten Native } \\
\text { advertising }\end{array}$ & $\begin{array}{lr}\text { Pertama; agreement } & \text { kedua } \\
\text { belah pihak. Kedua; melakukan } \\
\text { brainstorming r } r \text { untuk } \\
\text { menentukan konten yang } \\
\text { sesuai dengan produk yang }\end{array}$ & $\begin{array}{l}\text { Pertama; mendapatkan brief dari klien } \\
\text { berupa apa saja yang akan dikerjakan. } \\
\text { Kedua; apabila klien masih belum memiliki } \\
\text { konsep konten, maka akan dibuatkan } \\
\text { proposal yang berisi konsep konten, apabila }\end{array}$ & $\begin{array}{l}\text { Mulai dari penentuan } \\
\text { objektifitas dari } \\
\text { sebuah produk, lalu } \\
\text { memilih media mana } \\
\text { yang cocok dengan }\end{array}$ & \\
\hline
\end{tabular}




\begin{tabular}{|c|c|c|c|c|c|}
\hline & & $\begin{array}{lr}\text { akan disematkan. } & \text { Ketiga; } \\
\text { menyambungkan } & \text { antara } \\
\text { informasi editorial } & \text { dan } \\
\text { informasi produk agar terlihat } \\
\text { halus }\end{array}$ & $\begin{array}{l}\text { dari kedua belah pihak setuju, maka akan } \\
\text { berlanjut. Ketiga; budgeting, yaitu } \\
\text { menyesuaikan konsep dengan anggaran. } \\
\text { Keempat; setelah semua disetujui, maka } \\
\text { konten disebar. Kelima;controlling, dan } \\
\text { reporting untuk invoicing }\end{array}$ & $\begin{array}{l}\text { melihat dari } \\
\text { segmentasi dan data } \\
\text { traffic yang dimiliki. } \\
\text { Lalu baru melakukan } \\
\text { kesepakatan }\end{array}$ & \\
\hline \multirow[t]{2}{*}{$\begin{array}{l}\text { Penyebaran } \\
\text { Konten } \\
\text { Native } \\
\text { advertising }\end{array}$} & $\begin{array}{l}\text { Cara } \\
\text { Penyebaran }\end{array}$ & $\begin{array}{l}\text { Melalui website dan sosial } \\
\text { media seperti Line Official, } \\
\text { Facebook, Twitter, Instagram, } \\
\text { dan Youtube }\end{array}$ & $\begin{array}{l}\text { Selain dalam website, radio online dan sosial } \\
\text { media, biasanya konten juga akan di- } \\
\text { boosting pada akun sosial media berbayar } \\
\text { dan kanal berita lain, serta kerjasama } \\
\text { dengan influencer }\end{array}$ & $\begin{array}{lll}\text { Media } & \text { sosial dan } \\
\text { aplikasi } & & \end{array}$ & $\begin{array}{l}\text { website dan media } \\
\text { sosial }\end{array}$ \\
\hline & Perangkat & Smartphone dan PC/Laptop & smartphone & Smartphone & smartphone \\
\hline $\begin{array}{l}\text { Dampak } \\
\text { advertising }\end{array}$ & Konten & $\begin{array}{l}\text { Dapat menambah pendapatan } \\
\text { dan meningkatkan traffic } \\
\text { website terkait }\end{array}$ & $\begin{array}{l}\text { Menjadi sumber pendapatan dan } \\
\text { meningkatkan engagement audiens dan } \\
\text { efektif dalam menghasilkan awareness } \\
\text { namun tidak dapat mencapai keputusan } \\
\text { pembelian }\end{array}$ & $\begin{array}{l}\text { Menghasilkan } \\
\text { jangkauan yang luas, } \\
\text { tetapi belum cukup } \\
\text { berdampak bagi } \\
\text { affinity dan } \\
\text { pengambilan } \\
\text { keputusan untuk } \\
\text { tahap pembelian }\end{array}$ & $\begin{array}{l}\text { memberikan } \\
\text { wawasan seputar } \\
\text { informasi umum dan } \\
\text { produk terkait serta } \\
\text { dapat melakukan } \\
\text { pembelian apabila } \\
\text { tertarik, namun } \\
\text { jarang sekali terjadi }\end{array}$ \\
\hline
\end{tabular}

Sumber: Dinanti, 2020 


\section{Konten Digital Native advertising}

dreamers.id menghasilkan berbagai jenis konten native advertising seperti sponsored content, sponsored hyperlink listings, serta sponsored social media posts. Sponsored content dikemas dalam artikel di website. Desain konten native advertising dibuat persis dengan artikel editorial. Jenis artikel yang bisa diolah sebagai sponsored content berupa artikel informatif lifestyle maupun seputar tips. Biasanya pesan atau informasi merek ditaruh pada bagian akhir artikel seperti gambar 4 yang diberi kotak merah. Hal ini terkonfirmasi oleh informan 1 yang menyatakan: "jadi orang tuh sbenernya ga sadar kalo itu sbenernya adalah sponsored content gitu, nah itu di ujung, kaya aku cerita yang tadi biasanya, ee.. kita relate sama product yang mau dipromosikan gitu" (informan 1).

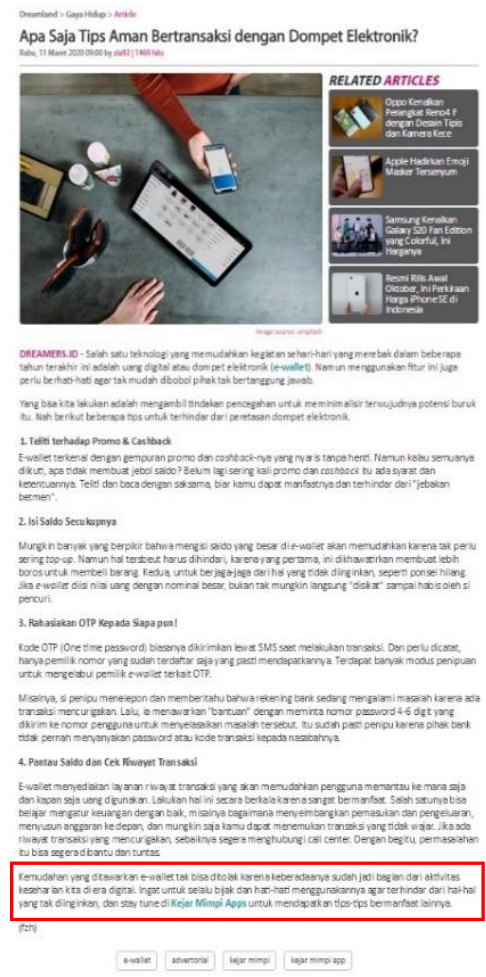

Gambar 4 Konten
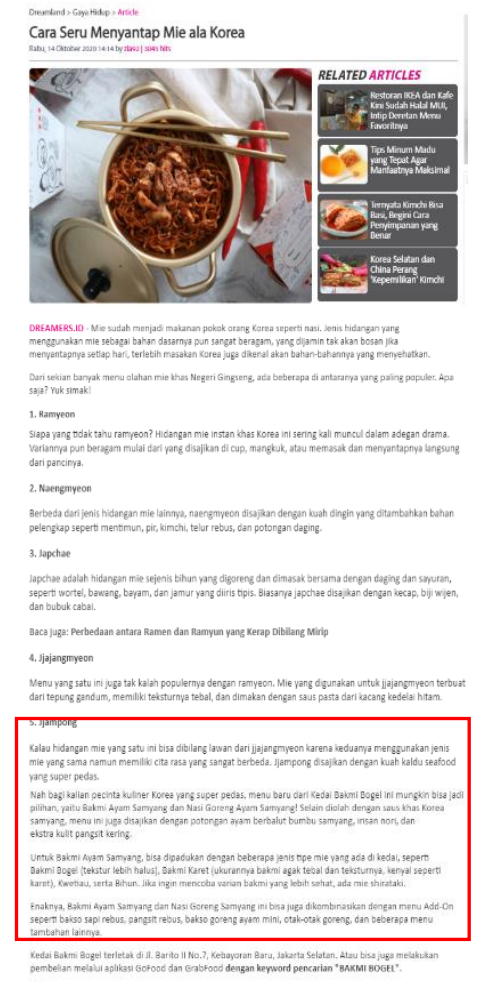

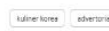
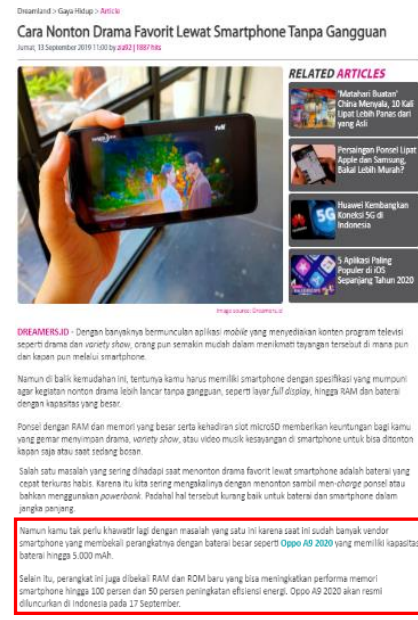

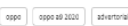

onsored Content dalam website dreamers.id Sumber : www.dreamers.id

Dalam menghasilkan sponsored hyperlink listings, dreamers.id bekerjasama dengan third party. Untuk jenis ini, dreamers.id menyebut sebagai programmatic ads. Third party akan memasukkan beragam konten bersponsor yang sesuai dengan 
segmentasi dreamers.id pada sela-sela daftar artikel di website sehingga terlihat serupa dengan konten artikel asli. Adanya tulisan "Sponsored by" menjadi pembeda dengan konten lainnya. Ketika artikel tersebut di-klik, maka langsung terhubung (hyperlink) dengan website lain yang berhubungan dengan artikel tersebut. Seperti dikatakan oleh informan 1: "orang ngeliatnya itu masih satu paket dengan konten yang ada di website, padahal sbenernya itu sponsored juga gitu" (informan 1).
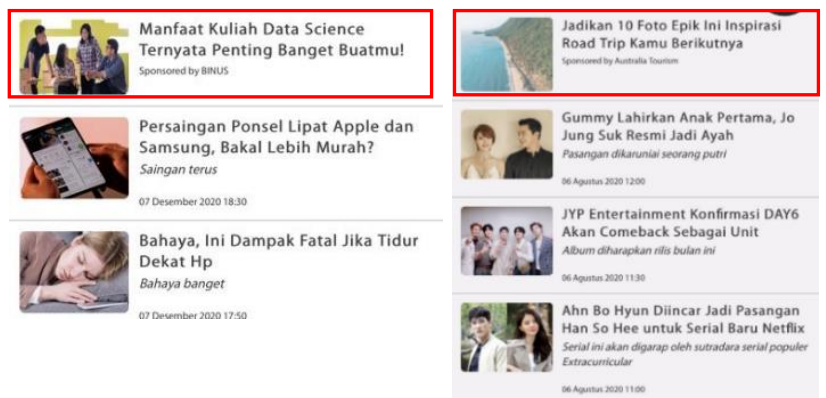

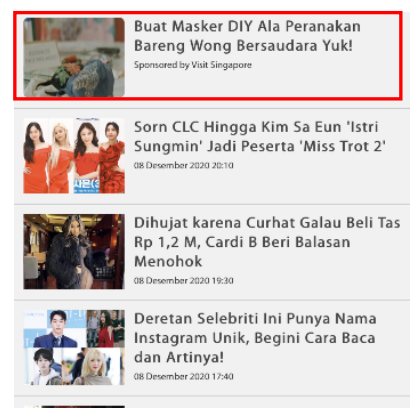

Gambar 5 Konten Sponsored Hyperlink Listings dalam mobile website dreamers.id Sumber : www.dreamers.id
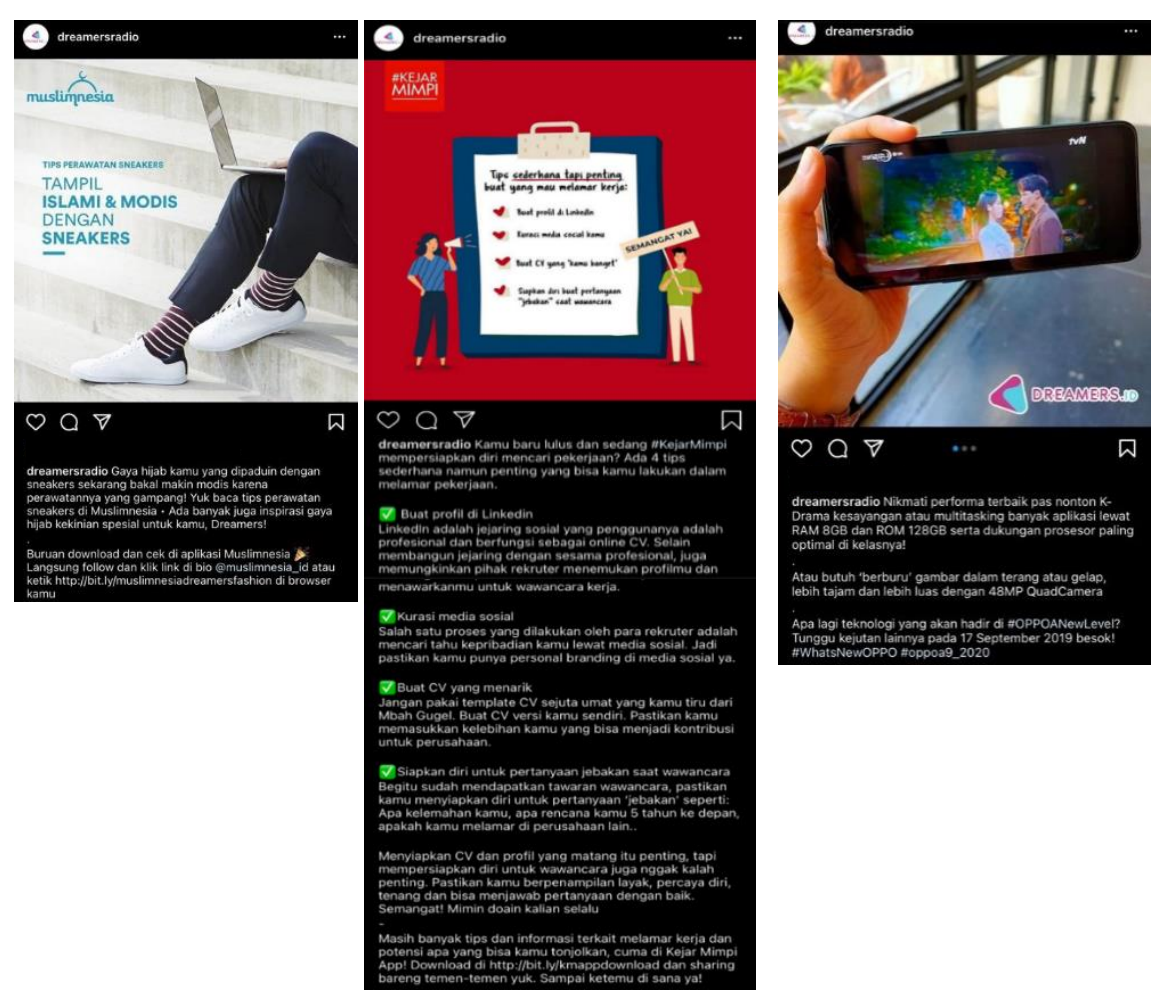

Gambar 6 Konten Sponsored Social Media Posts dalam website dreamers.id Sumber : Akun Instagram @dreamersradio

dreamers.id juga menghasilkan konten sponsored social media posts. Konten ini lebih digunakan sebagai penunjang penyebaran konten bersponsor yang telah 
dihasilkan pada website atau sebagai mirrorring content. Setiap unggahan dalam media sosial, konten ini menambahkan "\#advertorial” pada kotak deskripsi dan membubuhkan logo sponsor pada setiap poster yang diunggah. Hal ini dikatakan oleh informan 2: "sosial media itu biasanya mirroring dengan website gitu" (informan 2).

Dalam menghasilkan konten native advertising, dreamers.id mengacu pada pedoman jurnalistik yang disesuaikan dengan karakteristik, identitas dan segmentasi audiens, lalu mengaitkannya dengan pesan suatu merek. Penggunaan label "advertorial" disematkan pada akhir artikel agar menjadi pembeda antara konten native advertising dengan konten lainnya serta memudahkan pencarian dalam arsip data. Konten native sendiri memuat dua informasi utama, yakni informasi editorial dan informasi mengenai merek. Informasi editorial berisi informasi ringan seperti tips \& trick, info perjalanan, tren, maupun gaya hidup yang masih sesuai dengan tema dari suatu produk yang akan dikaitkan. Informasi mengenai merek diletakkan pada bagian akhir yang memuat penjelasan singkat suatu produk dan link website produk terkait. Gaya penulisan juga dibuat persuasif. Hal tersebut dapat membangun engagement, mendorong audiens untuk mengkonsumsi konten, dan menarik audiens dalam jumlah besar. Informan 1 menyatakan bahwa: "format yang memang sudah menjadi kebiasaan disukai sama audiens kita (informan 1).

Ada beberapa tujuan yang ingin dicapai dari segi pengiklan dan media publikasi (dreamers.id). Dari segi pengiklan; mendapatkan awareness dan downloader dari audiens dengan jangkauan persebaran yang luas. Dari segi media publikasi (dreamers.id); mencapai KPI (Key Performance Indicator) yang dapat berupa visitor per click dan menghasilkan pendapatan. Selain itu juga dapat memperkaya varian artikel untuk website. Hal ini terkonfirmasi oleh informan 3 yang mengatakan: "tujuannya pasti nyari ini sih.. nyari awareness sama downloader, sama reach-nya juga sih, kan kalo melalui native ads itu kan lumayan gede ya, per visit" (informan 3).

Untuk mendapatkan awareness dan engagement dari audiens, dreamers.id selalu melakukan pengulangan iklan sesuai dengan timeline yang sudah ditentukan. Penyesuaian timeline disesuaikan dengan budget dan frekuensi konten yang akan tayang (publish) dengan tetap mengoptimalkan semua platform yang dimiliki untuk 
mendapatkan eksposure yang lebih tinggi. Sebagaimana dikatakan oleh informan 2 bahwa: "dengan budgetnya sekian dapet semua slot, tapi nanti diatur lagi frekuensinya untuk tayang di semua platform yang kita punya" (informan 2).

dreamers.id melakukan beberapa tahap dalam memproduksi konten native advertising. Pertama, setelah melakukan kesepakatan dengan account executive, pengiklan akan memberikan arahan yang berisi informasi sebuah produk. Lalu, pihak redaksi membuat konsep konten native advertising yang sesuai dengan produk tersebut dengan membuat proposal. Kemudian, apabila pengiklan setuju dengan konsep tersebut, tim account executive menyusun anggaran. Setelah semua berjalan, konten akan dipublikasikan pada semua platform media online yang dimiliki (tergantung perjanjian awal). Selanjutnya, masuk pada tahap controlling yang dilakukan dari pihak redaksi dan account executive untuk memastikan semua berjalan sesuai timeline. Setelah itu reporting untuk invoicing. Hal ini terkonfirmasi oleh informan 2 yang menyatakan bahwa: "harus membuat kesepakatan agar si iklannya ini berjalan. Trus yang kedua, monitoring, kalo sudah dapet native ads harus monitoring, e.. ketiga ada reporting, yang terakhir adalah invoicing" (informan 2).

\section{Penyebaran Konten Native advertising}

Untuk menyebarkan konten native advertising, dreamers.id menggunakan website, radio online, sosial media berupa Line Official, Facebook, Twitter, Instagram, dan Youtube serta komunitas. Adanya lingkup komunitas anak muda terutama komunitas kpop dalam dreamers.id juga mempengaruhi engagement yang dihasilkan. Dengan adanya komunitas, dreamers.id lebih mudah menghubungkan suatu produk sesuai dengan target audiens yang dituju. Persentase audiens dreamers.id pada perangkat mobile lebih besar dibanding pengguna desktop. Maka dari itu, penyebaran beragam konten termasuk konten native advertising lebih ditingkatkan terutama pada perangkat mobile seperti melakukan boosting dalam akun sosial media berbayar dan kanal berita lain, serta kerjasama dengan influencer. hal ini dinyatakan oleh informan 2: "caranya macam-macam, bisa kita boosting, di account sosial media berbayar, atau kita kerjasama sama influencer" (informan 2). 


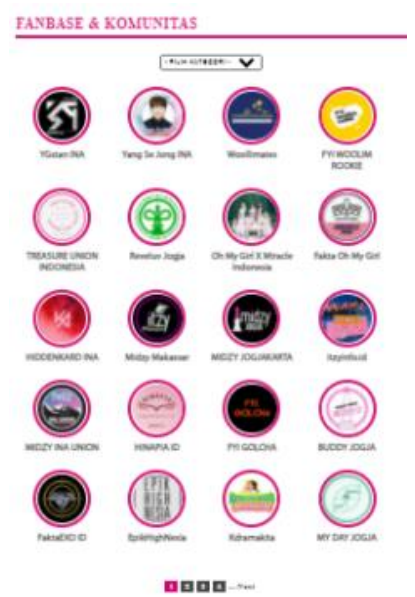

Gambar 7 Lingkup komunitas dreamers.id Sumber : www.dreamers.id

\section{Dampak Konten Native advertising}

Konten native advertising berdampak bagi dreamers.id seperti menghasilkan pendapatan, menambah traffic website yang terkait, dan meningkatkan engagement audiens. dreamers.id menilai konten native advertising cukup efektif dalam menghasilkan awareness audiens namun tidak berbanding lurus dengan keputusan pembelian karena memiliki dampak jangka panjang. Hal ini dikatakan informan 2 bahwa:"efeknya bisa berdasar jangka panjang. Untuk itu, ya awareness nya tetep bagus, kita selalu melakukan knowledge si product itu berulang kali" (informan 2).

Menurut pengiklan, native advertising belum dapat menimbulkan dampak seperti affinity dan pengambilan keputusan untuk mengkonsumsi suatu produk lebih lanjut sehingga penting untuk melakukan cara beriklan lainnya agar mencapai tujuan dari sebuah produk. Informan 3 mengatakan bahwa: "menurutku ga cuma satu tipe lah, kita boleh native ads, tapi harus ada iklan-iklan bentuk lain juga" (informan 3).

Menurut audiens, konten iklan native dapat menambah wawasan dari segi informasi umum maupun produk. Audiens tidak merasa terganggu, namun merasa sedikit bingung karena di awal artikel tidak terlihat seperti iklan. Apabila produk yang terkait membuat penasaran dan sesuai dengan kesukaan dan kebutuhan, audiens dapat melakukan pembelian. Namun, pembelian jarang terjadi dengan hanya melihat konten iklan native. Seperti yang dikatakan informan 4: "kalo produknya emang 
relate sama yang dicari dan sama yang aku suka pasti kan aku cari infonya lebih lanjut, trus aku beli, jadi ya bermanfaat" (informan 4).

Temuan pada penelitian ini menjelaskan bagaimana konten native advertising dapat bekerja dalam dreamers.id. Terdapat tiga kategori native advertising yang diproduksi yaitu sponsored content, sponsored hyperlink listings, dan sponsored social media posts. Semua konten native advertising dalam dreamers.id terlihat serupa dengan konten editorial berjenis informasi ringan. Namun, yang menjadi pembeda ialah informasi seputar merek dan memiliki label "advertorial" pada bagian akhir konten. Sebagaimana diatur oleh Peraturan Dewan Pers Nomor 1/PeraturanDP/III/2012 tentang Pedoman Pemberitaan Media Siber yang mengatakan harus mencantumkan keterangan yang menjelaskan artikel tersebut adalah iklan (Dewan Pers, 2017). Setiap kategori memiliki bentuk label "advertorial" yang berbeda. Pada kategori sponsored hyperlink listings mencantumkan keterangan "sponsored by" di bawah judul artikel karena sudah terprogram yang bekerja sama dengan third party. Untuk kategori sponsored content, label "advertorial" berada pada bagian bawah artikel agar tidak terkesan iklan apabila ditaruh pada bagian bawah judul seperti halnya sponsored hyperlink listings. Sedangkan pada kategori media sosial, label "advertorial" dicantumkan pada kolom caption dalam bentuk tanda pagar "\#advertorial" dan mencantumkan logo produk dalam poster terkait. Selain berfungsi sebagai pembeda, label "advertorial" juga memudahkan pencarian dalam arsip data.

Pengemasan visual konten native advertising pada dreamers.id terlihat serupa dengan konten editorial lainnya. Mulai dari segi tata letak, font, warna, gambar, serta kolom memiliki desain yang sama. Selain itu, situs harus dapat menyeimbangkan struktur dan hubungan dari menu atau homepage dengan halaman isi atau grafik dan dokumen yang ditautkan. Hal ini dapat membangun hierarki menu dan halaman sehingga memiliki struktur yang mudah digunakan oleh audiens (Lynch dan Horton, 2016). Layout harus mendukung isi konten agar dapat diterima dengan baik oleh audiens (Rustan, 2014). Sequence atau urutan dalam konten ini dapat ditangkap cukup baik. Alur paragraf dari kiri ke kanan membuat audiens tidak kesulitan dalam membaca konten yang dihasilkan. Hal ini memudahkan 
audiens dalam menangkap isi pesan. Untuk emphasis atau penekanan dalam dreamers.id tidak ada perbedaan yang signifikan baik dari segi ukuran, bentuk, warna, maupun peletakan. Semua terlihat serupa dengan konten editorial lainnya. Pada keseimbangan untuk tata letaknya sendiri terlihat memiliki kesan formal dan baku. Tidak ada pergerakan atau movement yang terlalu substansial dalam visual dreamers.id. Lalu, jika dilihat dari segi unity atau kesatuan, baik elemen fisik maupun non fisik menyatu dengan baik dan sepadan. Tidak terlihat adanya ketimpangan suatu elemen tertentu. Setiap konten native advertising yang dihasilkan memiliki visual yang konsisten sehingga enak dilihat oleh para audiensnya. Apabila dibandingkan dengan beberapa media online luar negeri, visual konten native advertising terlihat sangat berbeda. Hal ini dikarenakan data, informasi, dan pesan merek dikemas lebih bervariasi. Salah satunya seperti The Washington Post yang mengemas visual secara motion grafis, infografis, penambahan video, terdapat kuis singkat, dan 3D Motion.

Dalam membuat copywriting untuk konten native advertising, banyak divisi yang terlibat seperti account executive, pengiklan, dan kepala redaksi. Secara keseluruhan, konten native advertising dalam dreamers.id sekilas terlihat bukan seperti konten iklan karna memiliki visual yang mirip. Namun, apabila dilihat dari segi copywriting, ada beberapa perbedaan yang dapat dilihat. Dalam unsur tipografi, baik dalam pemilihan jenis dan ukuran huruf tidak ada perbedaan. Mulai dari jenis, desain, ketebalan, hingga ukuran huruf memiliki standar yang sama dengan konten editorial lainnya. Pada bagian headline dibuat sesuai dengan ciri khas dari dreamers.id yaitu membahas informasi seputar Korean Pop. Dalam membuat headline, dreamers.id menggunakan kata-kata yang singkat dan menarik untuk memikat audiens mereka. Perbedaan headline untuk konten native advertising ini biasanya singkat, menarik, dan lebih mudah dicerna. Dreamers.id menempatkan sub headline pada bagian thumbnail. Hal ini bertujuan untuk mendukung judul agar audiens semakin tertarik terhadap konten native advertising yang dibuat. Selanjutnya pada bagian bodycopy, isi tulisan memuat informasi-informasi yang sedang tren dan ringan. Biasanya tulisan juga didukung dengan gambar-gambar yang menarik sesuai dengan tema yang 
dibahas. Hal ini membuat audiens tertarik, tidak bosan dan dapat membaca tulisan secara keseluruhan. Pada bagian terakhir, closing word berisikan informasi halus seputar produk yang dipromosikan dan menambahkan tautan yang merujuk pada website produk tersebut.

Pada dasarnya, komponen konten native advertising terbagi menjadi dua yaitu, komponen yang memuat pesan informasi dan pesan merek (The Interactive Advertising Bureau (IAB), 2019). Dalam mengemas komponen informasi, dreamers.id memiliki pendekatan dengan membahas hal-hal apa saja yang viral, tren dan disukai segmentasi mereka. Konten native advertising yang informatif, menarik, dan tidak mengganggu (Tutaj dan van Reijmersdal, 2012) membuat ketertarikan lebih besar. Dengan mengaitkan informasi yang bersifat emosional, dapat membuat keterikatan audiens jauh lebih besar ketimbang hanya memberikan informasi seputar produk saja (Berger dan Milkman, 2012). Dalam hal ini, informasi yang sifatnya emosional dapat dilihat dari apa yang disukai dari segmentasi audiens dreamers.id yang berupa anak muda dan penggemar kpop. Lalu, di ujung konten disematkan pesan merek berupa informasi dan tautan website produk tersebut yang disampaikan secara halus dan persuasif. Peletakan semacam ini membuat visibilitas sebuah merek dan pesan iklan yang dicantumkan terlihat rendah (Wojdynski, 2016a). Hal ini membuat audiens tertarik karena tidak terlihat sebagai konten iklan. Berbeda dengan penelitian terdahulu yang menyebutkan bahwa konten yang hanya berisi fakta seputar produk saja dapat terus menjalin ikatan antara merek dan audiens (Ashley dan Tuten, 2015). Adanya lingkup komunitas anak muda dan kpop dalam dreamers.id juga turut serta meningkatkan ikatan tersebut.

Untuk menyebarkan konten native advertising, sarana yang digunakan ialah media online (Harms, Bijmolt dan Hoekstra, 2019). Berbagai platform seperti website, radio online, dan media sosial dikerahkan untuk menyebarluaskan berbagai konten native advertising. Kemudahan audiens dalam mengakses internet dimana pun dan kapan pun membuat jangkauan target audiens lebih luas (Haiqal dan Hidayat, 2017). Penelitian sebelumnya menyatakan bahwa peletakan konten harus menjamin efektivitas exposure yang didapatkan dengan budget yang tersedia (Harms, Bijmolt 
dan Hoekstra, 2017). Agar mencapai hal tersebut, beragam cara dilakukan oleh dreamers.id seperti menyebarkan konten native advertising di semua platform yang mereka miliki, melibatkan komunitas anak muda dan kpop, melakukan boosting dalam akun sosial media berbayar, kerjasama dengan influencer dan kanal berita lain.

Pada dasarnya, perbedaan perangkat mobile dan non-mobile memiliki respon yang berbeda (Irwansyah, 2017). Besarnya persentase audiens yang mengakses konten mereka melalui perangkat mobile. Hal ini membuat pihak dreamers.id lebih memaksimalkan semua platform yang dapat diakses melalui perangkat mobile.

Berdasarkan penelitian terdahulu, audiens ada yang merasa tertipu akan keutuhan informasi sebuah konten sehingga mengabaikan merek yang tersemat di dalamnya (Whittle dan Xue, 2018). Namun, informan audiens dalam penelitian ini menyatakan bahwa merasa sedikit terganggu karena di awal tidak ada ciri-ciri konten iklan, namun karena dikemas dengan menarik dan halus jadi masih dapat diterima. Audiens juga mendapatkan pengalaman baru dalam mengkonsumsi sebuah konten native advertising karena berbeda dengan konten iklan lainnya.

Berdasarkan penelitian yang telah dilakukan, konten native advertising memiliki berbagai dampak bagi dreamers.id. Konten iklan seperti ini dapat menjadi penghasilan alternatif bagi penerbit (Probst, Grosswiele dan Pfleger, 2013). Selain penghasilan, konten native advertising dapat menambah traffic website yang terkait, meningkatkan engagement audiens, dan awareness. Meskipun dapat menghasilkan awareness audiens terhadap suatu merek, konten native advertising ini belum cukup efektif untuk menghasilkan keputusan pembelian karena sifatnya yang mempengaruhi dalam jangka panjang. Maka dari itu, dreamers.id selalu melakukan pengulangan dan penyebaran konten secara maksimal agar dapat berdampak pada keputusan audiens.

Penelitian terdahulu mengatakan bahwa native advertising dapat menciptakan awareness (kesadaran), interest (ketertarikan), dan attitude change (perubahan sikap) audiens (Harms, Bijmolt dan Hoekstra, 2017). Dari segi pengiklan, mereka mempunyai tujuan yang menghasilkan affinity dan pengambilan keputusan untuk mengkonsumsi sebuah produk lebih lanjut. Dengan hanya beriklan dengan 
format konten native advertising saja, belum dapat mencapai tujuan tersebut. Maka dari itu, penting untuk melakukan cara beriklan lainnya agar mencapai tujuan sebuah produk.

Konten native advertising dikemas secara menarik sesuai segmentasi. Audiens menyukai konten yang memiliki ikatan emosional yang sesuai. Apabila produk yang disematkan dalam konten tersebut dirasa menarik, maka dapat dilakukan pembelian. Namun, hal ini jarang sekali terjadi karena informasi produk yang minim. Audiens perlu mencari informasi lebih dalam sebelum mengambil keputusan lebih lanjut. Audiens lebih dapat menerima konten yang memiliki kedekatan dengan mereka sehingga dapat membentuk awareness suatu merek, namun konten yang berisi informasional penting keberadaannya untuk membantu mendorong keputusan selanjutnya seperti keputusan pembelian (Harms, Bijmolt dan Hoekstra, 2017).

\section{KESIMPULAN}

Penelitian ini bertujuan untuk mengeksplorasi bagaimana native advertising sebagai konten media online dalam dreamers.id. Native advertising sendiri sering digunakan dreamers.id sebagai salah satu konten iklan yang bersifat halus. Berbeda dengan konten editorial, konten native advertising memiliki beberapa ciri seperti adanya label "advertorial", informasi sebuah produk, dan bersifat persuasif.

Hasil penelitian menunjukkan terdapat tiga kategori konten native advertising yang dihasilkan yaitu sponsored content, sponsored hyperlink listings, dan sponsored social media posts. Setiap kategori memiliki pendekatan berbeda namun berpola yang sama, yaitu memiliki pesan berupa informasi dan merek. Dari segi visual, desain konten native advertising tidak memiliki perbedaan yang signifikan dengan konten editorial. Dari segi copywriting, tidak terdapat perbedaan tipografi dengan konten lainnya. Namun, pada bagian headline, subheadline, dan bodycopy dikemas sedemikian rupa lebih ringan dan menarik. Selain itu, closing word juga disampaikan secara halus dengan penambahan tautan website produk atau merek terkait. 
Meskipun konten native advertising sudah disebar melalui berbagai platform yang dimiliki dreamers.id dan berhasil menciptakan awareness suatu produk terhadap audiens, namun belum mampu untuk menciptakan tujuan-tujuan lain dalam beriklan sehingga cara beriklan dalam bentuk lain masih diperlukan. Maka dari itu, selain menjaga dan meningkatkan kualitas konten serta memperluas penyebaran, dreamers.id juga dapat mengembangkan bentuk visual yang lebih dinamis dan interaktif untuk konten native advertising. Lalu, dreamers.id dapat membentuk tim khusus untuk memproduksi konten native advertising seperti yang telah dilakukan oleh beberapa media berita luar negeri agar dapat mengemas konten native advertising secara maksimal.

Keterbatasan penelitian ini adalah belum dapat dijadikan acuan secara umum terhadap native advertising sebagai konten dalam media online lainnya. Namun, penelitian ini diharapkan dapat memberi gambaran awal dan acuan dalam menerapkan konten native advertising dalam bidang komunikasi dan periklanan di Indonesia. Penelitian selanjutnya diharapkan dapat melengkapi kekurangan dalam penelitian ini, baik dalam segi cara pengumpulan data, pendekatan, dan sudut pandang yang berbeda melalui sampel informan yang lebih bervariasi untuk mendapatkan cakupan penelitian yang lebih menyeluruh.

\section{DAFTAR PUSTAKA}

Agustrijanto (2006) Seni Mengasah Kreatifitas dan Memahami Bahasa Iklan. Bandung: Remaja Rosdakarya.

Alexa (2020) Competitive Analysis, Marketing Mix and Traffic, alexa.com. Available at: https://www.alexa.com/siteinfo/dreamers.id\#section_competition (Accessed: 3 November 2020).

Apostol, N.-E. (2020) 'What Is Known About Native Advertising in Editorial Contexts? A Descriptive Literature Review', Journal of Media Research. Babes-Bolyai University, 13(2(37)), pp. 59-81. doi: 10.24193/jmr.37.4.

Aribarg, A. dan Schwartz, E. M. (2020) ‘Native Advertising in Online News: Trade-Offs Among Clicks, Brand Recognition, and Website Trustworthiness', Journal of 
Marketing Research, 57(1), pp. 20-34. doi: 10.1177/0022243719879711.

Ashari, M. (2019) Jurnalisme Digital: Dari Pengumpulan Informasi Sampai Penyebaran Pesan, Inter Komunika: Jurnal Komunikasi. Available at: https://journal.interstudi.edu/index.php/InterKomunika/article/view/286 (Accessed: 12 November 2020).

Ashley, C. dan Tuten, T. (2015) 'Creative Strategies in Social Media Marketing: An Exploratory Study of Branded Social Content and Consumer Engagement', Psychology and Marketing. Wiley-Liss Inc., 32(1), pp. 15-27. doi: 10.1002/mar.20761.

Bakshi, A. (2015) 'Why and How to Regulate Native Advertising in Online News Publications', Journal of Media Law \&amp; Ethics, 4. Available at: https://www.academia.edu/12383891/Why_and_How_to_Regulate_Native _Advertising_in_Online_News_Publications (Accessed: 27 August 2020).

Berger, J. dan Milkman, K. L. (2012) 'What Makes Online Content Viral?', Journal of Marketing Research, 49(2), pp. 192-205. doi: 10.1509/jmr.10.0353.

Carlson, M. (2014) 'When news sites go native: Redefining the advertising-editorial divide in response to native advertising', Journalism, 16(7), pp. 849-865. doi: $10.1177 / 1464884914545441$.

Dewan Pers (2012) Pedoman Pemberitaan Media Siber. Available at: https://dewanpers.or.id/kebijakan/pedoman (Accessed: 27 August 2020).

Dewan Pers (2017) Buku Saku Wartawan. Cetakan Ketujuh. Jakarta : Dewan Pers. Available at: https://dewanpers.or.id/assets/ebook/buku/1905160429_2017-

08_BUKU_Saku_Wartawan_Cetakan_ke-7.pdf (Accessed: 13 October 2020). dreamers.id (2020) dreamers.id - About Us. Available at: http://www.dreamers.id/about-us (Accessed: 27 August 2020).

Federal Trade Commission (2015) Commission Enforcement Policy Statement on Deceptively Formatted Advertisements. United States of America. Available at:

https://www.ftc.gov/system/files/documents/public_statements/896923/15 
1222deceptiveenforcement.pdf (Accessed: 27 August 2020).

Haiqal, M. K. dan Hidayat, S. (2017) 'Penerapan Identitas Visual Pada Media Promosi Website Wisata Kerajinan Rajapolah', Desain Komunikasi Visual, Manajemen Desain dan Periklanan (Demandia), 2(02), pp. 182-199. doi: 10.25124/demandia.v2i02.934.

Harina, S. (2019) Kajian Copywriting Iklan Bukalapak, Tokopedia dan Shopee Kategori Bulan Ramadhan. Universitas Komputer Indonesia. Available at: http://elibrary.unikom.ac.id (Accessed: 21 January 2021).

Harms, B., Bijmolt, T. H. A. dan Hoekstra, J. C. (2017) 'Digital Native Advertising: Practitioner Perspectives and a Research Agenda', Journal of Interactive Advertising. Taylor \& Francis, 17(2), pp. 80-91. doi: 10.1080/15252019.2017.1357513.

Harms, B., Bijmolt, T. H. A. dan Hoekstra, J. C. (2019) 'You don't fool me! Consumer perceptions of digital native advertising and banner advertising', Journal of Media Business Studies. Taylor and Francis Ltd, 16(4), pp. 275-294. doi: 10.1080/16522354.2019.1640517.

Hatzios, A. dan Lariscy, R. W. (2008) 'Perceptions of Utility and Importance of International Public Relations Education among Educators and Practitioners', Journalism \& Mass Communication Educator. SAGE Publications Ltd, 63(3), pp. 241-258. doi: 10.1177/107769580806300304.

Irwansyah, I. (2017) 'Emosional Pengguna Dalam Mengakses Aplikasi Situs Non Mobile Dan Mobile', InterKomunika. STIKOM INTERSTUDi, 2(2), p. 123. doi: 10.33376/ik.v2i2.31.

Kim, B.-H., Pasadeos, Y. dan Barban, A. (2001) 'On the Deceptive Effectiveness of Labeled and Unlabeled Advertorial Formats', Mass Communication and Society. Informa UK Limited, 4(3), pp. 265-281. doi: 10.1207/s15327825mcs0403_02.

Lynch, P. J. dan Horton, S. (2016) Web Style Guide, 4th Edition: Foundations of User Experience Design. 4th Editio. Yale University Press.

Manzilati, A. (2017) Metodologi Penelitian Kualitatif: Paradigma, Metode, dan 
Aplikasi. Malang: Universitas Brawijaya Press(UB Press).

Poerwandari, E. K. (2007) Pendekatan Kualitatif untuk Penelitian Perilaku Manusia.

Depok: Lembaga Pengembangan Sarana Pengukuran dan Pendidikan Psikologi (LPSP3) Fakultas Psikologi Universitas Indonesia.

Probst, F., Grosswiele, L. dan Pfleger, R. (2013) 'Who Will Lead And Who Will Follow: Identifying Influential Users In Online Social Networks: A Critical Review And Future Research Directions', Business and Information Systems Engineering. Gabler Verlag, 5(3), pp. 179-193. doi: 10.1007/s12599-013-0263-7.

Pujiriyanto (2005) Desain Grafis Komputer (Teori Desain Grafis Komputer). Yogyakarta: ANDI.

Del Rey, J. (2013) Buzzfeed is Building a Native-Advertising Network. Available at: https://adage.com/article/digital/buzzfeed-building-a-native-advertisingnetwork/240421 (Accessed: 26 August 2020).

Romli, A. S. M. (2014) Jurnalistik online : panduan praktis mengelola media online. Bandung: Nuansa Cendikia.

Rustan, S. (2014) LAYOUT, Dasar dan Penerapannya. Jakarta: PT Gramedia Pustaka Utama.

Schauster, E. E., Ferrucci, P. dan Neill, M. S. (2016) 'Native Advertising Is the New Journalism: How Deception Affects Social Responsibility', American Behavioral Scientist, 60(12), pp. 1408-1424. doi: $10.1177 / 0002764216660135$.

Siapera, E. (2017) Understanding New Media. 2nd Editio. London: SAGE Publications Ltd.

Sirrah, A. (2019) Native Advertising May Jeopardize The Legitimacy Of Newsrooms. Available at: https://www.cjr.org/tow_center/native-ads-endangernewsrooms.php (Accessed: 27 August 2020).

Sugiyono (2008) Memahami Penelitian Kualitatif. Bandung: CV. Alfabeta.

Syahrial, Munadi, K. M. dan Mardatillah, N. (2010) 'Analisa Statistik Pengunjung Situs Resmi Universitas Syiah Kuala', Jurnal Rekayasa Elektrika, 9(2), pp. 49-54. doi: 10.17529/jre.v9i2.165. 
T Brand Studios (2014) PAID POST by Netflix - Women Inmates Separate But Not Equal. Available at: https://www.nytimes.com/paidpost/netflix/womeninmates-separate-but-not-equal.html (Accessed: 8 December 2020).

Tarigan, I. A. (2015) Apa Itu Native Advertising? Available at: https://www.medcom.id/teknologi/poptech/ybD9qRPk-apa-itu-nativeadvertising (Accessed: 27 August 2020).

The Atlantic (2019) Blood, Sweat and Data - IBM - The Atlantic Sponsor Content. Available at: https://www.theatlantic.com/sponsored/ibm-how-technologytransforms/blood-sweat-and-data/164/ (Accessed: 8 December 2020).

The Interactive Advertising Bureau (IAB) (2019) IAB Native Advertising Playbook 2.0, lab.Com.

Tutaj, K. dan van Reijmersdal, E. A. (2012) 'Effects of online advertising format and persuasion knowledge on audience reactions', Journal of Marketing Communications. Taylor \& Francis Group , 18(1), pp. 5-18. doi: 10.1080/13527266.2011.620765.

Vranica, S. (2016) Advertisers Try New Tactics to Break Through to Consumers. Available at: https://www.wsj.com/articles/advertisers-try-new-tactics-tobreak-through-to-consumers-1466328601 (Accessed: 24 September 2020).

Wang, R. dan Huang, Y. (2017) 'Going Native on Social Media: The Effects of Social Media Characteristics on Native Ad Effectiveness', Journal of Interactive Advertising, 17(1), pp. 41-50. doi: 10.1080/15252019.2017.1326327.

Whittle, C. dan Xue, F. (2018) 'Native Advertising on TV: Effects of Ad Format and Media Context', Online Journal of Communication and Media Technologies, 8(3), pp. 203-214. doi: 10.12973/ojcmt/2651.

Wojdynski, B. W. (2016a) 'Native Advertising: Engagement, Deception, and Implications for Theory', The New Advertising: Branding, Content and Consumer Relationships in a Data-Driven Social Media Era., (September), pp. 203-236. doi: 10.7151/dmgt.1373.

Wojdynski, B. W. (2016b) 'The Deceptiveness of Sponsored News Articles: How Readers Recognize and Perceive Native Advertising', American Behavioral 
Scientist. SAGE Publications Inc., 60(12), pp. 1475-1491. doi: 10.1177/0002764216660140.

Wojdynski, B. W. dan Evans, N. J. (2016) ‘Going Native: Effects of Disclosure Position and Language on the Recognition and Evaluation of Online Native Advertising', Journal of Advertising. Routledge, 45(2), pp. 157-168. doi: 10.1080/00913367.2015.1115380.

Wu, M. et al. (2016) 'A Tale of Two Sources in Native Advertising: Examining the Effects of Source Credibility and Priming on Content,Organizations, and Media Evaluations', American Behavioral Scientist, 60(12), pp. 1492-1509. doi: $10.1177 / 0002764216660139$. 